of the first mate penetrated the immature ova and eventually took part in controlling the development of offspring by subsequent mates.

Up to the end of last century Lord Morton's experiments with a male quagga and a young chestnut seven-eighths Arabian mare were regarded as affording strong evidence of telegony. Hence at the outset I decided to repeat as accurately as possible Lord Morton's experiment. The quagga being extinct, a Burchell zebra was mated with Arab and other mares belonging to different breeds and strains. The mares, after producing one or more hybrids, were mated with Arab and other stallions.

In an account of my experiments, illustrated by numerous figures, published in the Transactions of the Highland and Agricultural Society of Scotland for 1902, it is pointed out that, though, to start with, I believed there was such a thing as telegony, I eventually came to the conclusion that "there never has been an undoubted instance of infection in either dogs, rabbits, or horses." Though a full account of my investigations, by Mr. Hermon C. Bumpus, appeared in the American Naturalist (December, r899), and an abstract was published in the I9Io Report of the United States Bureau of Animal Industry, it is related in a recent American work on evolution ${ }^{1}$ that the idea of telegony "rests mainly upon what are known as the Penycuik experiments (Ewart, I899), the initial one of which was the impregnation of a mare, 'Mulatto,' by a quagga, a species of zebra which is now extinct. The offspring of this union was the foal 'Romulus,' which showed the quagga-stripes of his father very distinctly. Later, 'Mulatto' was bred to a pure Arab stallion and her second foal also showed traces of stripes, although by no means as distinctly as his halfbrother 'Romulus.' . . . Definite instances are neither numerous nor well authenticated with the exception of the one in question, and even this may be due to some other cause."

It is scarcely necessary to say that I am not responsible for the idea of telegony-without going far afield, Lull might have discovered that the doctrine of "infection " had been dealt with by Agassiz and was especially associated with a mare belonging to Lord Morton-but it may be as well to point out that I used a Burchell zebra (the quagga had been extinct for nearly a quarter of a century); that the hybrid "Romulus," instead of being striped like his sire, approached in his markings the very richly striped zebra of Somaliland; and that the two subsequent foals of "Mulatto" were decidedly less suggestive of zebras than pure-bred foals of a near relative of "Mulatto" who had never even seen a zebra.

In I9I0, when giving a course of lectures in Iowa, I gathered that the doctrine of telegony had few adherents in America. This view is supported by a statement in the recent work by Jordan and Kellogg, who "think it probable that the phenomena called telegony have no real existence."

\title{
PROGRESS OF CHEMISTRY.
}

\section{By Sir Edward Thorpe, C.B., F.R.S.}

$T^{H}$ $\mathrm{HE}$ half-century which has elapsed since the first issue of NATURE has witnessed an extraordinary development of science in general, but in no department has it been more marked, or the changes more profound, than in chemistry. Before dealing with the period over which the existence of this journal extends, it may not be uninteresting to indicate, in the broadest possible outline, the main features of progress in chemical science to which the growth we have witnessed during the last fifty years is in reality due.

The opening years of the nineteenth century constituted a new era in the history of chemical science. The revolution initiated by Lavoisier and his associates--Morveau, Laplace, Monge, Berthollet, and Fourcroy-was by this time accomplished, and its influence had extended throughout Europe. The French chemists, who emancipated chemistry from the thraldom of a false German doctrine, swept phlogistonism into the limbus fatuorum of extinct heresies. The early years of that century saw the passing of the more prominent adherents of Stahl's philosophy; of the English chemists, Priestley died in 1804, and Cavendish, who for some years

1 Luill, "Organic Evolution." (New York: The Macmillan Co.) NO. 2610 , VOL. IO4] previously had ceased to pursue chemical inquiry, followed him six years later.

Within the first quarter of the century appeared some of the most eminent of those who were destined to consolidate the principles upon which the New Chemistry was founded. Dumas and Wöhler were born in 1800 , Liebig in 1803 , Graham in 1805 , Laurent in 1807 , Gerhardt in 1816 , Wurtz, Kopp, and Marignac in $18 \mathrm{I} 7$, Kolbe and Hofmann in 1818 , Pasteur in 1822 , Alexander Williamson in 1824 , and Edward Frankland in 1825 . But there was already a generation at work the members of which, although not specially distinguished for their direct contributions to speculative chemistry, yet served by their labours to strengthen the foundations upon which it is based; among them were Wollaston and Davy, born in 1766 , and Gay-Lussac, born in 1778 . Berzelius, who was born in 1779 , first published his electro-chemical theory in 1827 . A revolution scarcely less momentous than that of Lavoisier had, moreover, by this time been effected by John Dalton; the enunciation of the atomic theory in $1807-8$ wholly altered the aspect of chemistry; henceforth it was brought within the domain of mathematics, and its laws and processes were established on a 
quantitative basis. It consummated a change which Cavendish may be said to have originated. It can be proved that Cavendish was cognisant of the principles underlying what we term the "law of constant proportion" and the "law of reciprocal proportion"; that he foresaw that the facts embodied in these laws are at the foundation of all quantitative analytical work, and that in his practice he implicitly recognised their truth.

In spite of the widespread political and social disturbance which marked the early years of the last century, a tide in the affairs of chemistry then set in, which, with periods of ebb and flow, reached a high-water mark at the time this journal was founded.

The first two decades of the century not only witnessed the establishment of the fundamental laws of chemical combination and their rational explanation by means of the atomic theory; they also saw the enunciation of the gaseous laws; the discovery and application of voltaic electricity as an analytic agent; the isolation of the metals of the alkalis and alkaline earths; the determination of the nature of the halogens; and the discovery of many new metallic elements. In 1802 these were only twenty-three in number, as against sixty-three at the present time. They saw, too, the discovery of fulminating mercury and fulminating silver, acetylene, carbonic oxide, phosgene-some of which have played a large part in the Great War, but which when first made known were regarded as mere chemical curiosities, incapable of application. This period also saw the invention of the miner's safety lamp and the creation of the gas-lighting industry-two new departures of which it is impossible to exaggerate the consequences, immediate and remote. It witnessed also the discovery of isomorphism, the enunciation of the law of Dulong and Petit, and the first synthesis, by Wöhler, of an organic product.

The third decade brought us Faraday and the discovery by him of tetrachlorethylene and perchlorethane; the liquefaction of the gases; the isolation of benzene; the preparation of naphthalene sulphonic acids; and the formulation of the laws of electro-chemical decomposition. It witnessed also the activity of Graham; the promulgation of the law of gaseous diffusion; the recognition of the basicity of acids and the constitution of salts; the establishment of the doctrine of compound radicals by Liebig and Wöhler; the discovery by Dumas of chlorine substitution and the publication of his theory of types. It saw also the death of Wollaston and Davy, and the birth of Cannizzaro, Berthelot, Kekulé, and Lothar Meyer. The early 'thirties are memorable, too, for the attempts made to regularise chemical notation and for the gradual adoption of the system of Berzelius.

But, with the exception of the work of Graham and Faraday, the decade $1830-40$ is not particularly remarkable for British contributions to chemical science. Although the volume of published work was no doubt considerable, it was NO. $26 \mathrm{rO}, \mathrm{VOL}$. IO4] not of the epoch-making order. As Edward Turner wrote, "the era of brilliant discovery in chemistry appeared to have terminated for the present." Thoughtful men deplored the condition of British science at this period, and they were concerned at the general apathy of the public with respect to it. One result of their action was the foundation, in 1831 , of the British Association for the Advancement of Science. At the same time, it cannot be said that Continental workers were much more active. Apart from those already referred to, we find no noteworthy contribution to the theory of chemistry. The extent of the retrogression in this country may be judged from the fact that at this time the number of communications to the various societies, and to scientific periodicals dealing with chemistry, was not much more than half of what it was in 1802 .

With the advent of the fourth decade there was a great awakening. It was signalised by the discovery of the first of the organo-metalloid radicals by Bunsen in $I 84 I$; the recognition of homology by Schiel in 1842 ; the early work of Pasteur on racemic acid; the synthesis of acetic acid by Kolbe; the dissociation of water by heat by Grove; the work of Frankland on ethyl and zinc-ethyl; the discovery by Wurtz of the compound ammonias and their synthetical formation by Hofmann; and the elucidation of the constitution of ether and the theory of etherification by Williamson. This decade was further made memorable by the creation, in I84I, of the Chemical Society of London, and by the foundation, in 1845 , of the Royal College of Chemistry. At that time organic chemistry was scarcely studied in this country, and schools of practical chemistry were very few in number here. English chemists who sought instruction in operative chemistry and in the methods of original investigation for the most part resorted to Liebig at Giessen or to Wöhler at Göttingen. Liebig soon made his influence felt abroad, and his memorable English tour in 1842 gave a strong stimulus to the study of chemical science in this country. One of its immediate effects was the foundation of the Royal College of Chemistry, with Hofmann, one of Liebig's most brilliant pupils, as its director.

This was the first institution of its kind in Great Britain in which chemistry was studied for its own sake, and not merely as subordinate to other professional training. Space does not permit of any detailed account of its activities, or of the circumstances which led to its absorption into the School of Mines. It is only necessary to recall the names of Warren de la Rue, Abel, E. C. Nicholson, How, Bloxam, Blyth, Price, Rowney, Muspratt, Mansfield, Field, Noad, Brazier, Medlock, Crookes, Spiller, Tookey, Church, Perkin, Groves, Valentin, Vacher, O'Sullivan, Duppa, McLeod, Reynolds, Griess, Holzmann, Martius, Geyger-among the most distinguished of Hofmann's pupils and coadjutors - to indicate the influence he exercised on the development of chemistry in Great Britain during 
the twenty years of his residence amongst us. That he should have been allowed to depart was nothing short of a national calamity.

As regards British contributions to chemistry during this and the succeeding decade, the most noteworthy may be said to have emanated from the Oxford Street institution. Williamson, however, was still active at University College, and to this period belongs Frankland's recognition, in $185 \mathrm{I}$, of the principle of valency. The synthetic colour industry originated in $185^{6}$ from Perkin's discovery of mauve, and Hofmann himself, with other of his pupils, contributed greatly to its development. As regards other workers, notable contributions to chemical theory at about this time were Clausius's work on electrolysis, Deville's studies on dissociation, Couper's conception of atomic linkage, and the resuscitation by Cannizzaro of Avogadro's hypothesis and his demonstration of its sufficiency at the memorable Congress of Karlsruhe in 1860 . The introduction of spectrum analysis by Bunsen and Kirchhoff belongs also to this epoch.

NATURE was founded at a time of extraordinary development in chemistry. Kekulé had made known his fruitful conception of the constitution of benzene, and a host of workers, more particularly in Germany, were exploiting with feverish activity the chemistry of the so-called aromatic compounds. The synthetic colour industry received a remarkable impetus by the synthesis of alizarin. Newlands had already adumbrated Mendeléeff's great géneralisation, of which the validity seemed to be established by the dramatic discovery, in quick succession, of the new elements it had predicted.

During the fifty years of its subsequent existence this journal has recorded and made intelligible to the general public every notable advance in chemistry. It has witnessed great and fundamental changes in the science. New conceptions have arisen and time-honoured doctrines have been modified or altogether supplanted. Chemical knowledge has been augmented by the inclusion of the theories of stereo-isomerism, desmotropy, the gaseous theory of solutions and free ions, and the Walden inversion. It has had to note and describe the methods of liquefaction of all the socalled permanent gases, and it has seen the universal recognition of the principles, first indicated by Andrews, on which the change of physical state depends. It has chronicled the discovery of argon by Rayleigh, and that of terrestrial helium, krypton, neon, and xenon by Ramsay. It has seen the rise and progress of radio-activity, the isolation of radium and its associates, and the discovery of isotopic elements. Lastly, it has seen a profound change in our conception of the Daltonian atom as an indivisible entity, and a strengthening of our belief in the intimate connection between matter and energy.

Throughout the whole of its existence NATURE has been true to the ideals which it established at its birth, and has been consistently faithful to the traditions it created. It has insisted from the outset that national progress must be based upon new ideas, and that the main source of new ideas is original research. It has shown that the greatest practical realities of our time have originated from the search for truth; that inven. tion waits upon discovery--the most powerful of all agents of civilisation; and that new knowledge means new power. Hence it has with a uniform insistence pointed out that it is the duty of the State, in its own interest, to encourage and foster research and to remove the hindrances which beset the pursuit of science and impede its progress. Nor has its advocacy been based solely on the lower ground of material advantage, or on the fact that original research has proved to be the source of new industries and of wealth-that it creates employment and alleviates labour. It has striven to show that mental and moral progress have a scientific basis-that our knowledge of Nature and the universe, our modes of thought, our criteria of truth, our detection and avoidance of fallacies, are dependent upon that habit of mind we call "scientific"-a habit which can be cultivated and strengthened only by the study and pursuit of science.

It has a record of which it may justly be proud. By the manner in which it has discharged its functions and fulfilled its obligations, it has earned the gratitude of all men of science, and it now celebrates its jubilee with the knowledge that it has merited, and will receive, the unstinted appreciation of all true lovers of science.

\section{CHEMISTRY IN THE MAKING.}

\section{By Prof. Henry E. Armstrong, F.R.S.}

$\mathrm{T}$ HE period covered by Nature happens to be that which just comes within my ken. In chemistry, both pure and applied, it has been one of astounding progress and fulfilment. Frankland and I published our new method of water analysis-involving combustion in vacuo with the aid of the Sprengel pump-in the year of its birth: people then ran their sewage into a cesspit and drank the water from an adjoining well. Typhoid fever was rife throughout the land. NO. 26 IO, VOL. IO4]
Bacteriology was an unknown science. Frankland's work on the Rivers Commission gave the nation a pure-water supply and contributed greatly to a complete sanitary system, in this respect placing us ahead of the world. The systematic use of the Sprengel pump dates from our inquiry; Crookes afterwards used it in constructing his radiometers.

It is noteworthy that sulphuric anhydride was a laboratory curiosity at that time: when I 